International Journal on Emerging Mathematics Education (IJEME)

Vol. 1, No. 2, September 2017, pp. 205-210

P-ISSN: 2549-4996, E-ISSN: 2548-5806, DOI: http://dx.doi.org/10.12928/ijeme.v1i2.5708

\title{
Krulik and Rudnik Model Heuristic Strategy in Mathematics Problem Solving
}

\author{
1Uus Kusdinar, 2Sukestiyarno, ${ }^{2}$ Isnarto, 1 Afit Istiandaru \\ ${ }^{1}$ Universitas Ahmad Dahlan, Jalan Prof. Dr. Soepomo, S.H Yogyakarta \\ ${ }^{2}$ Universitas Negeri Semarang, Sekaran Gunungpati Semarang \\ e-mail: uus.kusdinar@pmat.uad.ac.id
}

\begin{abstract}
Abstrak
Strategi heuristik merupakan salah satu strategi pemecahan masalah matematika untuk mendapatkan hasil efektif. Penelitian ini bertujuan untuk menggali, mengelompokkan, dan menganalisis strategi heuristik berdasarkan modifikasi model Krulik dan Rudnik, sehingga dapat dijadikan dasar untuk memberikan pendampingan dalam pembelajaran. Penelitian ini merupakan penelitian kualitatif yang melibatkan 32 siswa SMP Muhammadiyah 4 Yogyakarta sebagai subjek penelitian. Variabel penelitian ini adalah indikator-indikator penggunaan heuristik model Krulik dan Rudnik, meliputi: read and think, explore and plan, select a strategy, find and answer, serta reflect and extend. Penelitian ini menggunakan metode kuesioner dan wawancara. Hasil penelitian menunjukkan bahwa: 2 siswa $(6,25 \%)$ berada pada kategori baik dengan lebih sering melakukan semua strategi heuristik; 21 siswa $(65,62 \%)$ berada pada kategori cukup dengan melakukan sebagian strategi heuristik; dan 9 siswa (28,13\%) berada pada kategori kurang menunjukkan penggunaan strategi heuristik. Pada semua kategori, indikator find and answer lebih sering dilakukan siswa sedangkan indikator explore and plan masih jarang dilakukan.
\end{abstract}

Kata Kunci: pemecahan masalah matematika, strategi heuristik, model Krulik dan Rudnik

\begin{abstract}
Heuristic strategy is one of the mathematics problem solving strategies to gain effective results. This research aimed to analyze the use of the heuristic strategies based on the modification of the Krulik and Rudnik model. This research discovered and classified the students' heuristic strategies which can be used as a basis to provide assistance in the learning. This research was a qualitative research involving 32 students of SMP Muhammadiyah 4 Yogyakarta as its subjects. The research variables are the indicators of the Krulik and Rudnik heuristic models which the students performed including: read and think, explore and plan, select a strategy, find and answer, as well as reflect and extend. The data was taken through questionnaire and interview methods. The result suggested that: 2 students (6.25\%) were in the good category as they did all of the heuristic strategies more often; 21 students $(65.62 \%)$ were in the fair category since they implemented some indicators of the heuristic strategies; and 9 students $(28.13 \%)$ were in the poor category since they were lack in implementing the heuristic strategies. In all categories, indicator of find and answer was more oftenly done by the students while the indicator of explore and plan was less done.
\end{abstract}

Keywords: problem solving, heuristic strategy, Krulik and Rudnik model

How to Cite: Kusdinar, U., Sukestiyarno, Isnarto, \& Istiandaru, A. (2017). Krulik and Rudnik model heuristic strategy in mathematics problem solving. International Journal on Emerging Mathematics Education, 1(2), 205-210. http://dx.doi.org/10.12928/ijeme.v1i2.5708

\section{INTRODUCTION}

At the end of the decade of the 80s, a paradigm shift in the study of mathematics was initiated by the National Council of Teachers of Mathematics in America in 1989 with the introduction of Curriculum and Evaluation Standards for School Mathematics, 
where problem-solving and reasoning become the main objectives in the school mathematics (NCTM, 1989). The changes in mathematics learning paradigm was later adapted into the curriculum in many countries as well as in Indonesia. One of the goals of school mathematics learning is the ability to solve problems (Goodnough \& Hung, 2008; MOEC, 2016; Putra, Herman, \& Sumarmo, 2017). Therefore, problem solving has become an important focus in school mathematics curriculum started from primary school level to the high school level (Istiandaru, Istihapsari, Wardono, \& Mulyono, 2015; Park Rogers, Cross, Gresalfi, Trauth-Nare, \& Buck, 2011).

According to Polya (1988), the problem solving activities consist of four steps, namely: (1) understanding of the problem (See), (2) planning the problem solving (Plan), (3) carrying out the plan (Do), and (4) checking the solution (Check). This is a common heuristic model as the basis for the development of more detailed problem solving process. Along with the steps above, another steps of problem solving have also been proposed, namely reading, analisys, exploration, planning/implementation, and verification (Goos, Galbraith, \& Renshaw, 2000).

Meanwhile, Krulik \& Rudnik (1995) introduces the five stages of problem solving as heuristic. Heuristic is steps in getting things done without having to be done sequentially. The five steps are: (1) Read and Think: identify the facts, identify the questions, visualize the situation, explain the settings, and determine the next action; (2) Explore and Plan: organize information, find out if there is information appropriate/necessary, find whether there is information that is not needed, drawing/illustrating the model of the problem, as well as create charts, tables, or images; (3) Select a Strategy: find/create a pattern, working backwards, try and do, simulations or experiments, simplification or expansion, create a list of sequential, logical deduction, as well as divide or categorize the problem becomes a simple matter; (4) Find and Answer: predicting, using numeracy, using algebra capabilities, using geometric capabilities, as well as using a calculator if necessary; (5) Reflect and Extend: recheck the answers, determine alternative solutions, develop answers to other situations, developing response (generalization or conceptualization), discuss the answers, as well as create a variety of problems that the origin of the problem.

This research aimed to analyze the heuristic strategies in solving mathematics problems based on the modification of the Krulik and Rudnik model (Krulik \& Rudnik, 1995). This research discovered and classified students heuristic strategies that can be a basis to give assistance in problem based learning.

\section{RESEARCH METHOD}

This research focuses on the thinking process of the junior high school students in solving mathematics problems. There were 32 seventh grade students of SMP Muhammadiyah 4 Yogyakarta selected using a random sampling technique to be the research subjects. The research variables are the indicators of the Krulik and Rudnik heuristic models which the students are used to perform including: read and think, explore and plan, select a strategy, find and answer, as well as reflect and extend. A questionnaire was used to to explore what students think to solve problem using heuristic strategies. Furthermore, an in-depth interview was conducted to know more about the strategies. The indicators used were adopted from the heuristic strategies indicators by Krulik and Rudnik (1995). Elaboration of the indicators can be seen in Table 1.

IJEME, Vol. 1, No. 2, September 2017, 205-210. 
Table 1. Description of the heuristic strategies indicators used in problem solving

\begin{tabular}{|c|c|c|}
\hline No & Indicator & Description \\
\hline 1 & Read and Think & $\begin{array}{l}\text { 1.1. Students write what is given in the problems. } \\
\text { 1.2. Students write what is asked in the problems. } \\
\text { 1.3. Students explain the setting/situation of the problems. } \\
\text { 1.4. Students determine the next action to solve problems. }\end{array}$ \\
\hline 2 & Explore and Plan & $\begin{array}{l}\text { 2.1. Students select and organize information found in the } \\
\text { problems. } \\
\text { 2.2. Students find appropriate information required to } \\
\text { solve the problems. } \\
\text { 2.3. Students find information which is not required to } \\
\text { solve the problems. } \\
\text { 2.4. Students make illustration, model, or drawing. } \\
\text { 2.5. Students create charts or tables. }\end{array}$ \\
\hline 3 & Select a Strategy & $\begin{array}{l}\text { 3.1. Students find a pattern within the problems. } \\
\text { 3.2. Students solve the problems by working backward. } \\
\text { 3.3. Students use trial and error strategy. } \\
\text { 3.4. Students make simulation or experiments. } \\
\text { 3.5. Students make simplification or expansion. } \\
\text { 3.6. Students suggest chronological steps to solve } \\
\text { problems. } \\
\text { 3.7. Students use deductive logical way of thinking to solve } \\
\text { problems. } \\
\text { 3.8. Students perform categorization and distribution to } \\
\text { simplify the problems. }\end{array}$ \\
\hline 4 & Find and Answer & $\begin{array}{l}\text { 4.1. Students predict or estimate the solution. } \\
\text { 4.2. Students calculate without tools to solve problems. } \\
\text { 4.3. Students use algebraic ability to solve problems. } \\
\text { 4.4. Students use geometric ability to solve problems. } \\
\text { 4.5. Students use calculator (if allowed) to solve problems. }\end{array}$ \\
\hline 5 & $\begin{array}{l}\text { Reflect } \\
\text { Extend }\end{array}$ & $\begin{array}{l}\text { 5.1 Students review the solution obtanined from a } \\
\text { problem solving. } \\
\text { 5.2 Students make alternative solutions different from the } \\
\text { previous one. } \\
\text { 5.3 Students develop solution to another situation. } \\
\text { 5.4 Students make a generalization or conceptualization. } \\
\text { 5.5 Students discuss the solution with their friends. } \\
\text { 5.6 Students create a variety of problems derived from the } \\
\text { previous problem. }\end{array}$ \\
\hline
\end{tabular}

Modified from the heuristic model of Krulik and Rudnik (1995).

The data analysis used triangulation to confirm the findings. It is a process of data analysis by comparing the information or data obtained through questionnaires and interviews. This research followed the following steps: (1) giving the questionnaire of the heuristic strategies used in problem solving to students; (2) analyzing the results; (3) conducting interviews to some students representing group category: good, fair, and poor; (4) analyzing the results of questionnaires and interviews. 


\section{RESULTS AND DISCUSSION Results}

The result of questionnaire on the use of heuristic strategies in mathematics problem solving suggests that among the 32 students, we can grouped them into 3 categories: $6.25 \%$ were in the good category, $65.62 \%$ were in the fair category, and $28.13 \%$ were in the poor category. Furthermore, a recap of each heuristic indicator providing an average score with a maximum score of 4 can be seen in Table 2 .

Table 2. The average scores of each heuristic strategy indicators

\begin{tabular}{lcc}
\hline \multicolumn{1}{c}{ Indicator } & Score & Category \\
\hline Read and Think & 2.494 & Fair \\
\hline Explore and Plan & 2.363 & Poor \\
\hline Select a Strategy & 2.449 & Fair \\
\hline Find and Answer & 2.644 & Good \\
\hline Reflect and Extend & 2.583 & Fair \\
\hline
\end{tabular}

An interview was conducted to confirm the indicator with poor category. It was the indicator of explore and plan and below is the part of its transcripts. We present two questions to representative of each category.

$\begin{array}{ll}\text { Question 2a } & : \begin{array}{l}\text { Do you organize the information by identifying what is given, } \\ \text { what is the necessary and unnecessary information given in the } \\ \text { problem? }\end{array} \\ \text { Answer(Good) } & \begin{array}{l}\text { I often identify what is important or not important from the } \\ \text { given information. Usually I just do these problems by using } \\ \text { what is given. }\end{array} \\ \text { Answer(Fair) } & : \begin{array}{l}\text { I rarely get to choose what is important or not important, but I } \\ \text { work on the problem by using what is given. }\end{array} \\ \text { Answer(Poor) } & : \begin{array}{l}\text { I can not tell which information is important or not important to } \\ \text { solve these problems. However, I try to solve it. }\end{array} \\ \text { Question 2b } & : \begin{array}{l}\text { Do you make an illustration, drawing, model, or diagram of the } \\ \text { problem to be solved? }\end{array} \\ \text { Answer(Good) } & : \begin{array}{l}\text { I often use the illustration in a form of sketch or scribble and it } \\ \text { can be used to solve the problems. }\end{array} \\ \text { Answer(Fair) } & : \begin{array}{l}\text { Sometimes I make illustration, although only scribble as needed. } \\ \text { Answer(Poor) }\end{array}\end{array}$

Another findings are that the students actually do heuristic strategy to solve problems, but in different levels and indicators. They said that the heuristic strategies used from the highest to the lowest frequency are: find and answer, reflect and extend, read and think, select a strategy, and explore and plan. Explore and plan become the rarest they do for all categories.

\section{Discussion}

The results showed that students in general are doing heuristic strategies in mathematical problem solving. They are trying to solve the problem by answering questions, although in practice, the heuristic is not planned well.

IJEME, Vol. 1, No. 2, September 2017, 205-210. 
Students with good category often made illustrations when they work on a problem though the average score has not been optimum. The heuristic strategies used from the highest to the lowest frequency are: find and answer, reflect and extend, read and think, select a strategy, and explore and plan. Explore and plan becomes the rarest they do in this category.

A little bit similar to the previous one. Students with fair category use heuristic strategies from the highest to the lowest frequency respectively: find and answer, reflect and extend, read and think, select a strategy, and explore and plan. Explore and plan also becomes the rarest they do in this category. However, they show lower frequency to use illustration to solve a problem.

Meanwhile, the students with poor category said that they have never made any illustration to solve problems. The heuristic strategies they use from the highest to the lowest frequency are: find and answer, reflect and extend, select a strategy, read and think, and explore and plan. We see that the indicator of explore and plan still become the rarest heuristic they use to solve problem, but there is a different order with the other category. There was a shift between the indicator of select a strategy and read and think.

Furthermore, we present a matrix of the use of heuristic strategies in terms of the students' category at Table 3.

Table 3. The use of heuristic strategies in terms of the students category

\begin{tabular}{|c|c|c|c|}
\hline Indicator & Poor category & Fair category & Good category \\
\hline $\begin{array}{l}\text { Read and } \\
\text { Think }\end{array}$ & $\begin{array}{l}\text { Never/Rarely } \\
\text { performed }\end{array}$ & Rarely performed & Oftenly performed \\
\hline $\begin{array}{l}\text { Explore and } \\
\text { Plan }\end{array}$ & $\begin{array}{l}\text { Never/Rarely } \\
\text { performed }\end{array}$ & $\begin{array}{l}\text { Never/Rarely } \\
\text { performed }\end{array}$ & Rarely performed \\
\hline $\begin{array}{l}\text { Select a } \\
\text { Strategy }\end{array}$ & $\begin{array}{l}\text { Never/Rarely } \\
\text { performed }\end{array}$ & Rarely performed & Rarely performed \\
\hline $\begin{array}{l}\text { Find and } \\
\text { Answer }\end{array}$ & $\begin{array}{l}\text { Never/Rarely } \\
\text { performed }\end{array}$ & Rarely performed & Oftenly performed \\
\hline $\begin{array}{l}\text { Reflect and } \\
\text { Extend }\end{array}$ & $\begin{array}{l}\text { Never/Rarely } \\
\text { performed }\end{array}$ & Rarely performed & Oftenly performed \\
\hline
\end{tabular}

There are various causes which might influence the phenomena above. The teacher's perception and practice may become the strong cause. Several research suggest that teaching practice have strong link with the students' performance (Wenglinsky, 2002). Teachers who have never taught or made their students engaged with problems may cause their students are not accustomed to deal with problem solving. Furthermore, stimulus from teacher is also important to help the students learn (Hidayah, Pujiastuti, \& Chrisna, 2017). In a learning by using problem solving approach, teachers need to support and guide their students through scaffolding instruction enable management of learning task (Hillman, 2003). What we found in this research is that teacher has introduced various problems to the students but do not really provide a step by step procedure to solve mathematics problem. This is the importance role of teacher to also guide the students to use the heuristic strategies to deal with mathematics problems. 


\section{CONCLUSION}

The use of heuristic strategies has not been implemented well in the mathematics learning at SMP Muhammadiyah 4 Yogyakarta. Among the 32 students, there are 2 students $(6.25 \%)$ in the good category, 21 students $(65.62 \%)$ are in the fair category, and 9 students $(28.13 \%)$ are in the poor category. The students in the good category did all heuristic strategies more often. The students with the fair category performed most of the indicators of heuristic strategies. Meanwhile, the students with the poor category perform fewer indicators of heuristic strategies. In all categories, indicator of find and answer was more oftenly done by the students while the indicator of explore and plan was less done.

\section{REFERENCES}

Goodnough, K.C., \& Hung, W. (2008). Engaging teachers' pedagogical content knowledge: Adopting a nine-step problem-based learning model. Interdisciplinary Journal of Problem-Based Learning, 2(2), 61-90.

Goos, M., Galbraith, P., \& Renshaw, P. (2000). A money problem : A source of insight into problem solving action. International Journal for Mathematics Teaching and Learning, 1-21.

Hidayah, I., Pujiastuti, E., \& Chrisna, J. E. (2017). Teacher's stimulus helps students achieve mathematics reasoning and problem solving competences. Journal of Physics: Conference Series, 824, 11001.

Hillman, W. (2003). Learning how to learn : Problem based learning. Australian Journal of Teacher Education, 28(2), 1-10.

Istiandaru, A., Istihapsari, V., Wardono, \& Mulyono. (2015). Problem based learning (PBL) dengan pendekatan realistik-saintifik dan asesmen PISA untuk meningkatkan kemampuan literasi matematika. Edumatica, 5(1), 1-11.

Krulik, S., \& Rudnik, J.A. (1995). The new sourcebook for teaching reasoning and problem solving in elementary school. Boston: Temple University.

MOEC. (2016). The regulation of indonesian ministry of education and culture number 20/2016 about the graduate competence standard. Jakarta: BSNP.

NCTM. (1989). Curriculum and evaluation standards for school mathematics. Reston: National Council of Teacher of Mathematics.

Park Rogers, M. A., Cross, D. I., Gresalfi, M. S., Trauth-Nare, A. E., \& Buck, G. A. (2011). First year implementation of a project-based learning approach: The need for addressing teachers' orientations in the era of reform. International Journal of Science and Mathematics Education, 9(4), 893-917.

Polya, G. (1988). How to solve it: A new aspect of mathematical method (Second Ed.). Princeton: Princeton University Press.

Putra, D., Herman, T., \& Sumarmo, U. (2017). Development of student worksheets to improve the ability of mathematical problem posing. International Journal on Emerging Mathematics Education, 1(1), 1-10.

Wenglinsky, H. (2002). The link between teacher classroom practices and student academic performance. Education Policy Analysis Archives, 10(12), 1-30.

IJEME, Vol. 1, No. 2, September 2017, 205-210. 